CHAPTER ELEVEN

\title{
LOST IN TIME AND SPACE? \\ GLOCAL MEMORYSCAPES IN THE EARLY MODERN WORLD
}

Dagmar Freist

\section{Memory Transmission Reconsidered}

The transmission of memory is a prerequisite for the emergence, continuity and change of memory cultures. However, for the early modern period, the ways in which memories were passed on and how they changed in the process have not been studied systematically. There has also been a lack of scholarly differentiation between the transmission of memories over time, from generation to generation and their transmission through space, for instance as a consequence of migration and the dispersion of people, written media and objects. This is partly due to the fact that until recently memory and commemoration have been the domain of national and comparative historiography. In spite of differences in their research agendas both Maurice Halbwachs and Pierre Nora, the pioneers of memory studies, with their emphasis on sites and sociabilities, made the nation state the focal point of memory formation. ${ }^{1}$ Nora's Les lieux de memoire, in particular, has found many imitators who defined national sites of memory such as the Deutsche Erinnerungsorte, on which Hagen Schulze and Francois Etienne edited an influential volume. ${ }^{2}$

Students of early modern memory need to develop different parameters in order to address the more fragmented but nevertheless collective perceptions of belonging which constitute the focal point of early modern memory formation and memory transmission. A distinctive issue for the period $1500-1800$ is the formation of collective memories which were not grounded within the confines of the nation-state but which were

${ }^{1}$ Maurice Halbwachs, On collective memory (Chicago: The University of Chicago Press, 1992), translated from: Les cadres sociaux de la mémoire (Paris: Presses Universitaires de France, 1952), originally published in Les Travaux de L'Année Sociologique (Paris: F. Alcan, 1925); P. Nora (ed.), Les lieux de mémoire, 7 vols. (Paris: Edition Gallimard, 1984-1992).

2 Etienne François and Hagen Schulze (eds.), Deutsche Erinnerungsorte, 3 vols. (Munich: C.H. Beck, 2001). 
generated in a dynamic between translocal developments and local circumstances. In this essay, religion will serve as a focal point of collective memory formation in the early modern period. Between the sixteenth and the eighteenth centuries, the conflicts between and within world religions, religious wars, the inquisitions and the prosecution of 'heretics', missionary programmes, religious print media and objects, rituals and dogma had a profound impact on collective memory formation across time and space.

Apart from the necessary reconsideration of what we might define as the focal points of memory formation in the early modern period, the analysis has to consider who were the agents in memory transmission. ${ }^{3}$ In this context, agency refers not only to people but also to media and material objects or 'things'. While people use objects to define and document their selves, things also enter and mark human lives. As tools of a practical nature or as keys to memory, things structure the actions and interactions of people. Things mark people's life stories, yet they also have their own biographies. This implies that we go beyond the idea of objects as 'memory containers' with a fixed meaning and also reject the notion of artefacts as 'repositories of memory', which are kept alive in memory transmission and which can be retrieved by cognitive acts of remembering these meanings and what they stand for. ${ }^{4}$ Instead, artefacts should be conceived of as co-actors of the social, in a network of references to varying meanings that are being bestowed on things by different actors in specific contexts and social practices. ${ }^{5}$ While the concept of the 'biography of things', first

${ }^{3}$ For the role of agents in transnational memory formation see Aleida Assmann and Sebastian Conrad, 'Introduction', in Aleida Assmann and Sebastian Conrad (eds.), Memory in a global age. Discourses, practices and trajectories (Basingstoke: Palgrave Macmillan, 2010), 1-16, there $2-4$.

4 Andrew Jones, Memory and material culture (Cambridge: Cambridge University Press, 2007), 42. In his essay on Global flows and local cultures, Helmuth Berking has stressed that 'place matters' for meaning and his ideas can be built upon for the relevance of social sites when looking at memory transmission as constituted in social practices. See Helmuth Berking, 'Global flows and local cultures. Über die Rekonfiguration sozialer Räume im Globalisierungsprozess', Berliner Journal für Soziologie 8 (1989), 381-392.

5 Whereas Bruno Latour proclaims the principle of symmetry between things and humans, others like Andrew Pickering admit that things help to constitute society but continue to focus on the human as the source of activities and practices. See for instance Bruno Latour, Reassembling the social. An introduction to actor-network-theory (Oxford and New York: Oxford University Press, 2005), Andrew Pickering, 'Practice and posthumanism. Social theory and a history of agency', in Theodore R. Schatzki, Karin Knorr Cetina and Eike von Savigny (eds.), The practice turn in contemporary theory (London and New York: Routledge, 2001), 163-174. See also Andrew Jones and Nicole Boivin, "The malice of 
introduced by Igor Kopytoff, emphasises the cognitive aspects behind the production of commodities, in which the object is 'culturally marked as being a certain kind of thing, ${ }^{6}$ the reconsideration of artefacts as participants in social practices addresses their relation to humans as constitutive of meaning. ${ }^{7}$ These processes of meaning-making do, of course, always depend on the specific sites of social practices. New social sites reconstitute social practices and in the process reconstitute memory formation and meaning, a process which can also be described as the re-memory of memory. In other words, 'human and non-human action is contextualised by social practices and arrangements in a specific sense'. ${ }^{8}$

Finally, we should not reduce memory to the cognitive act and/or competence of remembering, the ritual aspect of memory performance or the acknowledgement of collective memory sites. ${ }^{9}$ Instead, I want to propose a shift of analytical perspective by suggesting that memory formation and memory transmission are constituted in social practices around shared understandings which are defined as the 'skills, or tacit knowledge and presuppositions, that underpin activities' and need to be analysed as such. ${ }^{10}$ These social practices are construed as materially mediated activities, a perspective which acknowledges that 'things' help to constitute human sociability.

The aim of this essay is to map out a new analytical perspective on memory cultures and memory transmission during the transitory period

inanimate objects. Material agency', in Dan Hicks and Marie Claude Beaudry, The Oxford handbook of material culture studies (Oxford: Oxford University Studies, 2010), 333-351.

${ }^{6}$ Igor Kopytoff, 'The cultural biography of things. Commoditization as process', in Arjun Appadurai (ed.), The social life of things. Commodities in cultural perspective (Cambridge: Cambridge University Press), 64-91, there 64.

7 Andrew Jones has challenged the 'characterization of memory as an internalized cognitive function', and instead reconsidererd 'not only the wider role of human communities in the practice of remembering but also the participatory role of material culture in the process of remembering'. See Jones, Memory, 31 .

8 Michael Jonas, 'The social site approach versus the approach of discourse / practice formation', Reihe Soziologie / Sociological Series 92, 1-24, there 2. For the theoretical framework see Theodore R. Schatzki, The Site of the Social. A philosophical account of the constitution of social life and change (Pennsylvania: The Pennsylvania State University Press, 2002), esp. chpt. 3 .

9 Premodern memory studies have often focused on cognitive abilities and recall. See for instance the seminal study of Frances A. Yates, The art of memory (Chicago: University of Chicago Press 1966); A new approach has been suggested by Jones, Memory, esp. 6-13. See also Michael Rowlands, 'The role of memory in the transmission of culture', World Archaeology 25/2 (October 1993), 141-151.

10 Theodore R. Schatzki, 'Introduction. Practice theory', in Schatzki, Knorr Cetina and Von Savigny (eds.), The practice turn, 1-14, there 2. 
of early modern state formation. This requires a focus on the spatial as well as the diachronic dimension of memory. Memory transmission itself will be approached from the perspective of time with reference to generational memory and of space with reference to migration and the dispersion of people, written media and artefacts. It is here that the idea of being 'lost in time and space' comes in: 'Lost' in this context means the loss of a fixed and locally coded meaning through the de-contextualisation, reshaping and adaption of memory in the process of transmission and re-contextualisation in a new time and space. In the following I will first develop the concept of early modern 'glocal memoryscapes'. In a second step I will look at the phenomenon of memory transmission over time as memories are passed on, adapted, transfigured or suppressed from generation to generation. Thirdly, I will focus on the role of material culture for memory transmission. Here, too, my point of reference will be recent studies and theoretical approaches, which I will try to relate to early modern phenomena and sources. By way of conclusion I will argue that in processes of memory transmission and identity formation, time, space and things are intrinsically interrelated.

\section{Glocal Memoryscapes}

The emerging global turn in memory studies is a rather recent phenomenon, so far it has inspired mostly works focusing on the twentieth century. ${ }^{11}$ Among the first influential studies in this field is Daniel Levy's and Natan Sznaider's book The Holocaust and Memory in the Global Age of 2001. ${ }^{12}$ The authors analyze the Holocaust as a key to our understanding the construction of collective memory by demonstrating the competing cultural uses of the Holocaust in film, popular history, and social theories. According to their argument, memories of the Holocaust have been de-contextualised from the original event and offer a framework for interpreting contemporary acts of injustice such as ethnic cleansing and genocide. Building on this idea Aleida Assmann and Sebastian Conrad have argued in Memory in a Global Age that the nation is no longer the

11 John Sundholm, 'Visions of transnational memory', Journal of Aesthetics \& Culture 3 (2011), 1-5.

12 Daniel Levy and Natan Sznaider, Holocaust and memory in the global age (Philadelphia: Temple University Press, 2008), transl. by Assenka Oksiloff (first published as Erinnerung im globalen Kontext. Der Holocaust, Frankfurt/Main: Suhrkamp, 2001). 
'natural container of memory debates'. ${ }^{13}$ Instead, the interconnections of global frameworks and national memory discourses have to be analyzed; in other words, memory has to be studied from the angle of histoire croisée in its global entanglements. In their edited volume of collected essays on memory and migration, Julia Creet and Andreas Kitzmann point out that 'migration rather than location is the condition of memory', and they emphasise the connections between memory, place, and displacement. ${ }^{14}$

Whereas research on collective memories has recently discovered the transnational nature of memory formation in the twentieth century, this was actually also a central feature of early modern memory formation. From the fifteenth century on we can observe the formation of 'translocal memories', connecting people and places across time and space. This reconsideration of the spatial dimension of memory requires a specification of what is meant by 'space'. Here, it no longer refers to an administrative, constitutional, geographical or allegedly cultural unit but is emergent, that is, it is constituted and de-constituted through the interplay of social relations and practices, the attaching of meanings and interpretations, materiality and physical realities. Whereas the idea of space as emergent has been inspired by social theories, ${ }^{15}$ human geographers have re-defined the concept of landscape by emphasizing how inhabitation leads to the attribution of meaning and by proposing that landscape is a 'discovered subject'. ${ }^{16}$ Furthermore, the 'perceptions of and values attached to landscapes' 17 have been interpreted to 'encode values and fix memories to places that become sites of historical identity'. ${ }^{18}$ Landscape, so the argument goes, 'provides a context for the negotiation of place, memory and

13 Assmann and Conrad, 'Introduction', 6.

14 Julia Creet and Andreas Kitzmann, 'Introduction', in Julia Creet and Andreas Kitzmann (eds.), Memory and migration. Multidisciplinary approaches to memory studies (Toronto: University of Toronto Press, 2011), 9. See also Sundholm, 'Visions of transnational memory'.

15 Martina Löw, Raumsoziologie (Frankfurt am Main: Suhrkamp, 200o). For a wider discussion see the collection of essays by Jörg Döring and Tristan Thielmann (eds.), Spatial Turn. Das Raumparadigma in den Kultur- und Sozialwissenschaften (Bielefeld: Transcript, 2008).

16 Timothy Clack, 'Thinking through memoryscapes. Symbolic environmental potency on Mount Kilimanjaro, Tanzania', in T. Myllyntaus (ed.), Thinking Through the Environment. Green Approaches to Global History. (Cambridge: The White Horse Press, 2011), 115-134, there 116.

17 Ibid., 116.

18 Pamela J. Stewart and Andrew Strathern, 'Introduction', in Pamela J. Stewart and Andrew Strathern (eds.), Landscape, memory and history 83 (London, 2003), 83 and also Clack, 'Thinking', 116. 
community'. ${ }^{19}$ Translocal memories connect people and spaces, and they change in the process of transmission, so that the relevance and/or meaning of memories might have become lost in negotiations over memory in time and space. Memory and re-memory are evident in social practices and their relation to things and meanings.

Early modern re-memory was inseparably linked to both global and local memory cultures and can best be described by a concept that I should like to coin, that of the glocal memoryscape. In a variation on recent studies such as those by Kendall Philipps and Mitchell Reyes on global memoryscapes, ${ }^{20}$ the concept of glocal memoryscapes pays tribute to the interplay of local and translocal influences on memory thus 'collapsing the antinomy between the local and the global into the single, but complex, theme of the glocal'. ${ }^{21}$ The interplay of the local and the global is, first, based on networks which stretch across borders and are constituted by social relations, and secondly, it focuses 'on the spatial dimension of sociocultural life'. ${ }^{22}$ The term 'memoryscape' was originally coined by the discipline of human geography, and it implies an understanding of landscape as the product of an interrelation between culture, emotion, memory and the physical landscape. "The notion of the memoryscape is an expression of the convergence zone that homogenises these concepts'. ${ }^{23}$

How, then, can memory construction and memory transmission work in an early modern global setting? A prerequisite for 'memoryscapes' are global communication spaces in the form of social and cultural networks which bind people together across borders as well as a translocal perception of space as 'spatially projected reachability'. ${ }^{24}$ As an inhabited landscape, this space provides the platform for the negotiation, production and transmission of collective meanings of the past. Furthermore,

19 Clack, 'Thinking', 116. This refers to landscapes as lived and experienced space, filled with materiality and the meanings attributed to it by humans.

20 Kendall R. Phillips and G. Mitchell Reyes (eds.), Global memoryscapes. Contesting remembrance in a transnational age (Alabama: University of Alabama Press, 2011).

21 The concept of glocalization implies that the global is expressed in the local and the local is the particularization of the global. Roland Robertson, "The conceptual promise of glocalization. Commonality and diversity', consulted on 10 December 2012; and R. Robertson, 'Glocalization: time-space and homogeneity-heterogeneity,' in Mike Featherstone, Scott Lash and Roland Robertson (eds.), Global modernities (London: Sage, 1995), 25-44.

${ }^{22}$ Robertson, 'Conceptual promise'.

23 Clack, 'Thinking' 115: 'The memoryscape is a refinement of the conceptual maps of meaning promoted in the discipline of human geography.'

24 Translation by the author. Gerhard Hard, 'Der Spatial Turn, von der Geographie her beobachtet', in Döring and Thielmann (eds.), Spatial Turn, 263-315; there 292-293. 
according to Assmann, there have to be 'memory activists' and 'transnational memory alliances' at work, playing an active role in the construction of global memories and the transmission of memories in a global world. 25

The most elaborate glocal memoryscapes in the early modern period were those of diasporas. The term diaspora describes both the dispersion of people from their original homeland over different parts of the world and the community formed by such a people within their new place of residence, as well as across borders through family and religious networks. Whereas earlier research equaled diasporas with victims, more recent studies, first introduced by the sociologist Robin Cohen, also include those migrants into the concept of diaspora, who voluntarily left their homeland and maintained or formed a strong religious, cultural and/or religious identity abroad. ${ }^{26}$ A central feature of these diasporic communities were their close-knit networks, which extended across borders and also tied people together in a new environment based on family ties, ethnicity, religion, myths of origin and sociability, and - evolving from this - on trust and mutual dependence. ${ }^{27}$ The links were kept alive both through actual people on the move and, virtually, through correspondence and media which reiterated as well as constructed the sense of a closed community of shared and exclusive values and belief systems. A further characteristic of these diasporas was the awareness of 'belonging' to this group of people, the creation of an inner structure through things like poor relief, education, value systems, church formation, loan systems and trust, and loyalty towards one's own translocal group, as well as the construction of memory and narrative structures about belonging and identity.

In diasporas which were defined mainly by religion, it was obviously the clergy who served as important 'memory activists' by forming 'transnational memory alliances' through carefully designed correspondence networks in the production and circulation of newsletters. These networks

25 Assmann and Conrad, 'Introduction', 4, 9.

26 Robin Cohen, Global diasporas. An introduction (London: UCL Press and Seattle: University of Washington Press, 1997).

27 See Dagmar Freist, 'Uneasy trust relations, transcultural encounters and social change — diasporas in early modern Europe', in Sebastian Jobs and Gesa Mackenthun (eds.), Agents of transculturation. Border-crossers, mediators, go-betweens (Münster: Waxmann, 2013). Also Susanne Lachenicht and Kirsten Heinsohn (eds.), Diaspora identities. Exile, nationalism and cosmopolitanism in past and present (Frankfurt am Main: Campus Verlag, 2009) and Dagmar Freist and Susanne Lachenicht (eds.), Diasporas as translocal societies in the early modern period (forthcoming). 
aided in the construction of memories of a common root, nation and homeland (a constructed landscape independent of any real space), virtues, beliefs and practices. ${ }^{28} \mathrm{~A}$ case in point is the Protestant mission, the 'Danish-Halle Mission' which was founded in India in 1706 and which notwithstanding the worldwide dispersion of its members was based on a densely knit and highly controlled network and the permanent construction of belonging. All reports, diaries and letters sent from the various mission posts to the directors of the pietists who had their centre in the Saxon city of Halle (Germany) were censored and published as the first Protestant missionary journal, the Hallesche Berichte. ${ }^{29}$ These newsletters were introduced by prefaces which repeated and instilled religious identity through collective memories and were thus part of the pietist communication culture in a glocal sense of the word. ${ }^{30}$ Global communication spaces and the construction of a mutually inhabited religious landscape informed networks as their social and spatial reach developed through reports and letters sent in by members of the mission worldwide. Through their narratives they tried to establish their religious identity and values as separate from those of the 'heathen' world in which they worked and to reaffirm their belonging to a community of shared religious thoughts and deeds. These reports were censored in order to preserve a unified ideal of a pious life, religious practices and habitus based on the ideals of the Halle pietists.

A central question for further research will be to what extent these memories were gradually influenced and transformed by experiences of religious life in a diaspora in different parts of the world and through the encounter with other religious groups and cultures. We should also like to know how these experiences altered and complicated the construction of jointly inhabited landscapes of belonging. Correspondence with

${ }^{28}$ For a recent study on correspondence networks see for instance Gisela Mettele, Weltbürgertum oder Gottesreich. Die Herrnhuter Brüdergemeinde als globale Gemeinschaft 1727-1857 (Göttingen: Vandenhoeck \& Ruprecht, 2009).

29 'Der Königl. Dänischen Missionarien aus Ost-Indien eingesandter Ausführlichen Berichten, Von dem Werck ihres Amts unter den Heyden, angerichteten Schulen und Gemeinen, ereigneten Hindernissen und schweren Umständen; Beschaffenheit des Malabarischen Heydenthums, gepflogenen brieflichen Correspondentz und mündlichen Unterredungen mit selbigen Heyden ... Teil 1-9 (Continuation 1-108)', Halle, in Verlegung des Waysen-Hauses, 1710-1772 (Digital library http://192.124.243.55/digbib/hb.htm). For an English version of the digital library see http://192.124.243.55/cgi-bin/dhmeng.pl.

30 Cornelia Jaeger, Kontinuitäten und Diskontinuitäten in den Halleschen Berichten, unpublished master thesis, Oldenburg 2011; Ulrike Gleixner, Pietismus und Bürgertum. Eine historische Anthropologie der Frömmigkeit (Göttingen: Vandenhoeck \& Ruprecht, 2005). 
parties beyond these official newsletters casts a new light on these social networks and the emergence of social sites, as well as on social practices that are influenced by officially constructed memories and the interplay of global and local factors of memory transmission. ${ }^{31}$ Of special interest in this correspondence is the constitution of networks and forms of belonging which go beyond the officially defined diaspora and its ideals. Furthermore, the exchange of artefacts across the globe played a central role in these letters, as a vital part of social practice, memory transmission and the reconstitution of social sites.

Another form of glocal memoryscapes in the early modern period which has so far received little attention as a transnational/translocal phenomenon was the transmission of memories of martyrdom, defined as the commemoration of heroic deaths for religious reasons. Whereas these martyrologies could serve on the one hand as the basis of a national collective memory and help forge the nation state, as did John Foxe's Book of Martyrs ${ }^{32}$ in England, they also created a transnational awareness of belonging, because of the transmission of memories of suffering for religious reasons among co-believers across borders. ${ }^{33}$ 'Transnational alliances' of 'memory activists' were formed through the visualisation of martyrdom, the transmission and translation of the life stories of martyrs and finally through the de-contextualisation of martyrdom and the construction of 'martyrdom' as the epitome of religious steadfastness even in the face of persecution and death. Transnational alliances were evoked through the generalisation of suffering with religious brethren and sisters wherever they were oppressed. Memory transmission of both religious sufferings and belonging worked through the continuous reiteration of martyrdom and its material reproductions in the form of pictures and books from generation to generation, as we know from the study of inventories, testaments, woodcuts and art.

A final example of the de-contextualisation of events and memory culture and the subsequent narrative and material construction of glocal memoryscapes in the early modern period is the so-called leyenda negra, the Black Legend. The term is used to describe the complex of negative

31 See Dagmar Freist, 'Letters from Paramaribo. The Herrnhuter diaspora in the eyes of Catharina Borck', in Dagmar Freist and Susanne Lachenicht (eds.), Diasporas as translocal societies in the early modern period (forthcoming).

32 The Unabridged Acts and Monuments Online or TAMO (HRI Online Publications, Sheffield, 2011). Available from: http://www.johnfoxe.org (consulted on 30 December 2012).

33 Brad S. Gregory, Salvation at stake. Christian martyrdom in early modern Europe (Harvard: Harvard University Press, 2001). 
imagery of Spain and Spaniards that was created in numerous pamphlets, woodcuts, works of art and treatises from the sixteenth century onwards. ${ }^{34}$ The negative image was based on negative portrayals of the Spaniards which can be traced back to the thirteenth century and the work of the Spanish Inquisition but especially to the accusations which vilified the Spanish as a corrupt and cruel people who subjugated and exploited the New World Indians, stole their gold and silver, infected them with disease, and killed them in numbers without precedent. ${ }^{35}$ Bartolomé de las Casas' Brevísima relación de la destrucción de las Indias of 1552, which offered a critique of the behaviour of the Spanish conquistadores of the Americas, has often been described as the first published book to contribute to the Black Legend. This work was appropriated by groups and nations who opposed the Spanish Empire such as the Protestant Walloons, the French Huguenots, groups in Venice, and especially the rising powers of England and the Netherlands. In these reproductions and subsequent adaptations to other political contexts the 'Black Legend' was de-contextualised and emerged as an epitome of the cruelty exercised by the Spanish in general. A striking example is the anti-Spanish propaganda with which Netherlandish rebels attacked their Habsburg overlords during the Dutch Revolt in the sixteenth century, when the 'Black Legend' was re-membered and blended with memories of the cruelties committed by the Spanish in the Netherlands. In 1580, William I, Prince of Orange (1533-1584), who led the Dutch in their rebellion against Spanish Habsburg rule, declared that Spain 'committed such horrible excesses that all the barbarities, cruelties and tyrannies ever perpetrated before are only games in comparison to what happened to the poor Indians. ${ }^{36}$ The de-contextualisation of the 'Black Legend' from colonial Spain and its re-contextualisation in the Dutch Revolt in the process of memory transmission had as its objective

34 Friedrich Edelmayer, "The "leyenda negra" and the circulation of anti-catholic and anti-spanish prejudices' in European History Online (EGO), published by the Institute of European History (IEG), Mainz 2011-06-29, http://www.ieg-ego.eu/en/threads/modelsand-stereotypes/the-spanish-century/friedrich-edelmayer-the-leyenda-negra-and-thecirculation-of-anti-catholic-and-anti-spanish-prejudices, consulted on 15 February 2013.

35 For a critical reappraisal of the legend see B. Keen, "The Black Legend revisited. Assumptions and realities', The Hispanic American Historical Review 49 (1969), 703-719; and recently Margret Rich Greer, Maureen Quilligan and Walter D. Mignolo (eds.), Rereading the Black Legend. The discourses of religious and racial difference in the renaissance empires (Chicago: University of Chicago Press, 2008).

36 David Brion Davis and Steven Mintz (eds.), The boisterous sea of liberty. A documentary history of America from discovery through the civil war (Oxford: Oxford University Press, 2000), 39 . 
to legitimise the political breach with the Spanish Habsburg overlords. ${ }^{37}$ The term was coined in the nineteenth century by the Spanish historian Julián Juderías in his book La Leyenda Negra which was first published in $1914{ }^{38}$ It inspired a historiographical debate about how to analyse colonial history and created in response a 'white legend'. ${ }^{39}$ It also played a role during the Spanish Civil War and is reflected to this day in American attitudes towards Spanish migrants. ${ }^{40}$

\section{Memory Transmission over Time}

While memory transmission through space involves a complex process of decontextualisation, loss of meaning, adaptions and recontextualisations, the same can be said about the transmission of memories over time. To illustrate this, I will start from the micro-perspective of memory transmission within the family from generation to generation. In the course of the European Reformation many families were divided along religious and confessional lines, which influenced the practice and materiality of memory transmission within families and across generations. Generational studies have until recently focused on generation as an explanatory category in the process of periodisation or in understanding social dynamics. Alex Walsham, for instance, has shown how 'the notion of generational strife was invoked at various stages of England's long Reformation'. ${ }^{41}$ Other recent work has approached 'generation as a category of memory'

37 See Dagmar Freist, “The 'Dutch Century', in European History Online (EGO), published by the Institute of European History (IEG), Mainz 2012-10-17, http://www.ieg-ego.eu/en/ threads/models-and-stereotypes/the-dutch-century, consulted on 15 February 2013); Judith Pollmann, 'Eine natürliche Feindschaft. Ursprung und Funktion der Schwarzen Legende über Spanien in den Niederlanden 1560-1581', in Franz Bosbach (ed.), Feindbilder. Die Darstellung des Gegners in der politischen Publizistik des Mittelalters und der Neuzeit (Bayreuther Historische Kolloquien 6) (Cologne: Böhlau Verlag, 1992), 73-93, there 92.

38 Maria DeGuzman, Spain's long shadow. The Black Legend, off-whiteness, and AngloAmerican empire (Minneapolis, University of Minnesota Press, 2005).

39 For instance Benjamin Keen, 'The white legend revisited. A reply to Professor Hanke's "Modest proposal"', Hispanic American Historical Review 51 (1971), 336-355 and more recently with a critical review of the controversy A.L. Walsh, Arturo Pérez-Reverte. Narrative tricks and narrative strategies (London: Tamesis Books, 2007), 117.

40 DeGuzman, Spain's long shadow.

41 Quote from abstract of Alexandra Walsham, 'The Reformation of the generations. Youth, age and religious change in England, c. 1500-1700', Transactions of the Royal Historical Society, 6th Series, 21 (2011), 93-121. 
based on the understanding of memory as 'collective and social'. ${ }^{42}$ In this perspective memory is constructed rather than reconstructed through social interaction and communicative processes within the parameters of specific social milieus and their memory discourses. Generations define themselves, or are being perceived, as collective agents of these memory discourses and their inherent practices. Memory transmission as a form of bonding is constituted in social practices imbued with implicit understandings of a collective memory and its materiality, which connect various landscapes, nature and the lived environment.

Central to all empirical studies and theories on generation is the question of the degree of universality of 'generational phenomena' and of how we grasp a generation analytically. Leopold von Ranke, one of the first scholars to deal with generation as an analytical category, defined a historical generation as a 'row of shining figures who themselves are closely related and in whose antithesis the development of the world continues to progress' ${ }^{43}$ In a pioneering way, the historian and social scientist Karl Mannheim tried to capture the historical significance of generation by introducing the category of 'experience' and of 'understanding of the world' in young age through the exposure to specific environments which shape the mind for later perceptions and experiences of the world. He argues that 'we will only talk about generational context when real social and intellectual contents create a link between individuals in the same generational stratum' and adds that 'those groups who, within the same generational context, experience events in different ways, form in each case different generational units'. ${ }^{44}$ Present research acknowledges the diversity within generations rather than seeking for generational universals. Nevertheless, there remains analytical value in the idea that certain generational groups have been exposed to specific contexts and milieus in the course of their lives, which shape their ways of understanding and relating to the world. In this sense, generation as a memory category in the context of the reformation is worth further research. How were the Reformation and the religious developments of this period of unprecedented upheaval later remembered by those who experienced them? What was the manner in which such memories evolved over time?

\footnotetext{
42 Ulrike Jureit, Generationenforschung (Göttingen: Vandenhoeck \& Ruprecht, 2006), 114-115 (translation by the author).

43 Ibid., 274 (translation by the author).

44 Ibid., 278.
} 
Memory transmission within early modern families could follow various trajectories. Especially in Protestant contexts autobiographical writings served as a tool for memory transmission to create a religious identity and a specific habitus from one generation to another. Such autobiographical texts were often addressed directly to the next generation in order to instill them with the wisdom and experience of their elders. The German historian Ulrike Gleixner has analysed numerous autobiographies and other writings by pietists and has shown how the practice and the narrative construction of pietism, as it was passed down from generation to generation, produced its own religious culture and habitus, and bonded each new generation through the transmission of memory and identity building as a specific religious and social group. ${ }^{45}$ Besides the written media for memory transmission and identity building within the family, there was also the material world of religious beliefs. Here we can count family portraits endowed with religious signifiers, church pews, public donations, graveyards and gravestones, as well as the domestic material culture of religious practices which was passed down from generation to generation. However, we do not yet have any systematic study of how specific groups of one generation related to the Reformation and the emergence of religious multiconfessionalism and how these differing experiences influenced memory transmission and the building of religious and family identities. 46

Correspondence among family members as well as autobiographies provides ample evidence of the strain put on families after the conversion of some of their members and the subsequent division of family bonds along religious lines. Depending on the scope of ensuing conflicts and emotions, such acts of conversion could enter the family memory as traumatic experiences and be used to keep other members in line. The same was true for mixed marriages which always implied the danger of conversion or at least of the bringing up of future children in the 'wrong' religion. ${ }^{47}$

An interesting case in point is the dynamic between migration, material culture and memory transmission within families in religious minorities such as, for instance, Catholics in England or Protestants in Austria who

\footnotetext{
45 Gleixner, Pietismus und Bürgertum, 349.

46 For a first conceptual approach see Walsham, 'Reformation and Generation'.

47 Dagmar Freist, Glaube-Liebe-Zwietracht. Konfessionellgemischte Ehen in Deutschland in der Frühen Neuzeit (Munich: Oldenbourg, forthcoming 2014).
} 
were not allowed to practice their faith in public. ${ }^{48}$ These religious minorities were able to lead a religious life because they 'experimented with a variety of new alternatives for worship, religious identity, and communal religious experience' and 'viewed their actions as negotiating between Catholic orthodoxy and practical necessity'. ${ }^{49}$ These religious practices had to be passed down from generation to generation and were linked to artefacts. If we take the materiality of religious practices seriously, we have to reconsider the restrictions on the use of religious objects and what this meant in everyday religious practices, to find out how such restrictions shaped experiences and eventually the transmission of memory. In a fascinating study, Richard Williams has shown the various uses to which playing cards were put as material mediators of Catholic religious practices among prisoners in the Tower of London in seventeenth-century England. ${ }^{50}$ Whereas for some these playing cards were simply a game, Catholics could employ them as objects of devotion, even fold them into small altars, thus recalling forms of devotion in social practices and instilling these artefacts with specific meanings.

For Protestants, both the instructions of parents and books were vital for the survival of their faith as a minority. Protestant books were not permitted in Catholic Austria, and Protestants who tried to practice their faith privately and in secret had to invent ways of hiding and recovering the materials they needed for their religious practices. ${ }^{51}$ We still have traces of these practices in the shape of book hiding places under chimneys, above doors, under floorboards or below the ceiling. ${ }^{52}$ Whereas later

48 Alexandra Walsham, "Yielding to the extremity of time". Conformity, orthodoxy, and the post-Reformation English Catholic community', in Peter Lake and Michael Questier (eds.), Conformity and orthodoxy in the English church, ca. 1560-1660 (Woodbridge 2000), 211-236; Rudolf Leeb, Martin Scheutz and Dietmar Weikl (eds.), Geheimprotestantismus und evangelische Kirchen in der Habsburgermonarchie und im Erzstift Salzburg (17./ 18. Jahrhundert) (Vienna and Munich: Böhlau, 2009).

49 Lisa McClain, Lest we be damned. Practical innovation and lived experience among Catholics in Protestant England, 1559-1642 (New York and London: Routledge, 2004), 4.

50 Richard L. Williams, 'Forbidden sacred spaces in Reformation England', in Andrew Spicer and Sarah Hamilton (eds.), Defining the holy. Sacred Space in Medieval And Early Modern Europe (Aldershot and Burlington, VT.: Ashgate, 2005), 95-115. I thank Kerstin von der Lieth for pointing this book out to me.

51 Gustav Reingrabner, 'Einige Bemerkungen zu Frömmigkeit und Glaube der österreichischen Geheimprotestanten', Österreichische Gesellschaft zurErforschung des 18. Jahrhunderts. Das achtzehnte Jahrhundert und Österreich, Jahrbuch der Österreichischen Gesellschaft (1994), 35-55.

52 Dietmar Weikl, 'Das Buch im Geheimprotestantismus', in Johannes Frimmel and Michael Wögerbauer (eds.), Kommunikation und Information im 18. Jahrhundert. Das Beispiel der Habsburgermonarchie, Buchforschung 5 (Wiesbaden, Harrasowitz, 2005), 
generations might come across these 'gaps' in houses without recognising their past functions, family ties and generational links served as vital networks to provide the material culture needed in order to maintain religious practices in a diasporic situation. ${ }^{53}$ Thus, 'religious things' in the domestic culture of diasporas usually carried traces of other places and countries and so bore witness of religious oppression, identity and belonging; in other words, they connected to other landscapes. At the same time, passing down such 'forbidden' religious things served to transmit memories of one's coreligionists' brave and pious survival in a hostile environment. Over time such objects could become tokens of piety, symbols of the struggle for religious freedom, or simply reminders of heroism and civil courage.

\section{Material Culture and Memory Transmission}

The role of materiality in the spatial (i.e. migration) and generational dimensions of memory transmission is important in 'figuring diasporic positioning and identity politics' but also in other forms of identity formation. ${ }^{54}$ In a way material culture is a stimulus for a re-memory of memories which is part of the process of retrieving and reconceptualising memories in a new time and space.

The role of things in memory transmission always depends on the specific usages inherent in their materiality and the meaning which is attributed to them. ${ }^{55}$ As is the practice today, early modern social actors were expected to know implicitly the correct usage of a thing based on its materiality, meaning and context. If they lost the implicit knowledge and skill of how to use it and to what end, the item lost its relevance in social practices and was simply no longer intelligible. It might, however, as in the

255-263; and Dietmar Weikl, 'Das religiöse Leben im Geheimprotestantismus in den habsburgischen Erblanden und im Erzstift Salzburg', in Leeb, Scheutz and Weikl (eds.), Geheimprotestantismus, 457-474.

53 Giorgio Riello, 'Things that shape history. Material culture and historical narratives', in Karen Harvey (ed.), History and material culture. A student's guide to approaching alternative sources (New York: Routledge, 2009), 24-46, there $26-32$.

54 Divya P. Tolia-Kelly, 'Locating processes of identification. Studying the precipitates of re-memory through artefacts in the British Asian home', Transactions of the Institute of British Geographers 29/3 (2004), 314-329, there 314.

55 For the relational understanding of meaning, competence and practices see Elizabeth Shove, Mika Pantzar and Matt Watson (eds.), The dynamics of social practice. Everyday life and how it changes (London: Sage, 2012). 
case of religious objects, still carry its mnemonic function-for instance that of being or of having been a relic. ${ }^{56}$ The meaning of a specific thing may shift from the useful to the forgotten object, from rubbish to a (rediscovered) collector's or cult object, or even to materialised memory in a museum or in the collective memory. ${ }^{57}$

As David Morgan and others have argued, religious belief is rooted in and sustained by material practice. ${ }^{58}$ In a recent study Carolyn Walker Bynum has shown that in the period between 1150 and 1550, an increasing number of Christians in Western Europe made pilgrimages to places where material objects-among them paintings, statues, relics, pieces of wood, earth, stones, and Eucharistic wafers-allegedly sprang into life through such activities as bleeding, weeping, and walking. ${ }^{59}$ By the fifteenth century such phenomena were at the heart of religious practice and polemic, and they became highly contested once some began to promote a turn to inward piety which rejected material objects of devotion. Consequently, the animation of images and the hostility to them on the part of iconoclasts constituted a parallel phenomenon in the course of religious fragmentation of Europe. Material culture and religious practices represented religious beliefs, and the transmission of things marked both religious belonging and its commemoration.

Students of the Reformation and religious pluralism have only gradually discovered the relevance of material culture both for the understanding of religious practices and for processes of religious subjectivisation or self-fashioning. Among the most important arguments in the present debate about relics and Protestantism is the claim that the material practices of Protestants must no longer be read as 'deviations from orthodoxy that bear witness to subconscious popular resistance to the reformation' but instead they have to be 'interpreted [...] as authentically Protestant phenomena'. ${ }^{60}$ Whereas studies on Catholicism have long emphasised the materiality of religious practices especially with reference to processions,

\footnotetext{
56 See Stefan Laube, Von der Reliquie zum Ding. Heiliger Ort-Wunderkammer-Museum (Berlin: Akademie Verlag 2011), 199-264.

57 For a discussion of material culture approaches see 'AHR conversations. Historians and the study of material culture', American Historical Review 2009, 1355-1404.

58 David Morgan (ed.), Religion and material culture. The matter of belief (London: Routledge, 2009). See also the journal Material Religion. The Journal of Objects, Art and Belief published since 2005 by Berg journals.

59 Caroline Walker Bynum, Christian materiality. An essay on late medieval Europe (New York: Zone Books, 2011).

60 Alexandra Walsham, 'Introduction', in Alexandra Walsham (ed.), Relics and remains (Past and Present Supplement 5 (Oxford: Oxford University Press, 2010), 1-36, there 23. See
} 
pilgrimages and relics, new research on the material culture of Protestantism has focused on relics, the transformation of relics into things and the importance of a 'cult of things' for religious practices and 'the ways in which Protestantism engendered its own forms of material culture'. ${ }^{61}$ Similarly, the relevance of material culture for memory transmission is only now being addressed in religious studies. An interesting example is the famous St. Elizabeth glass, whose 'biography' or 'career steps' have been recently reinterpreted by Stefan Laube. ${ }^{62}$ Probably having come to Europe during one of the crusades, the glass came into the possession of a small Franciscan order near the Wartburg in the fourteenth century. About 1470 it travelled to the Weimar count, the Wettiner Wilhelm III. and his wife Katharina von Brandenstein, who were advanced in age but childless. In its new life, the glass was attributed with the power to bring about fertility, and it circulated as such among noble relatives of the couple. In the sixteenth century the glass regained its status as a holy relic and became part of the famous Wittenberg collection of relics, the traditional start for any public viewing of the relic chamber of Fredrick the Wise. By 1541 Martin Luther was recorded as the owner of the Elizabeth glass, and he seems to have used it in company during meals. A close friend noted: 'He reached across the table for a glass which was supposed to be the St. Elizabeth glass, filled it for himself and passed it around the table'. ${ }^{63}$

This quote is of interest for several reasons. It both refers to a glass as any vessel which was being used for drinking, and at the same time it evoked the memory of its sacred past by naming it 'the St. Elizabeth glass', which might have even been meant as a provocation. In spite of the evocation of this memory, its former sacred significance was lost in the process of memory transmission from one religious context to another. In other words, 'the Reformation involved a redefinition of the relic as a symbolic memento rather than as a miraculous divine entity' ${ }^{64}$ After 1541 we lose track of the glass' 'biography'; it entered its 'rubbish phase' until in 1910 it was rediscovered in Coburg. There it was acknowledged as a rare collector's item and its museum phase began. Given the current interest

also Ulinka Rublack, 'Grapho-relics. Lutheranism and the materialization of the world', in ibid., 144-166.

${ }^{61}$ Walker Bynum, Christian materiality; Laube, Von der Reliquie, 3-20; Walsham, 'Introduction', 23 .

${ }^{62}$ Laube, Von der Reliquie, 200-202. All references to the St. Elizabeth glass are based on these pages. Translations by the author.

${ }^{63}$ Laube, Von der Reliquie, 201.

64 Walsham, 'Introduction', 22. 


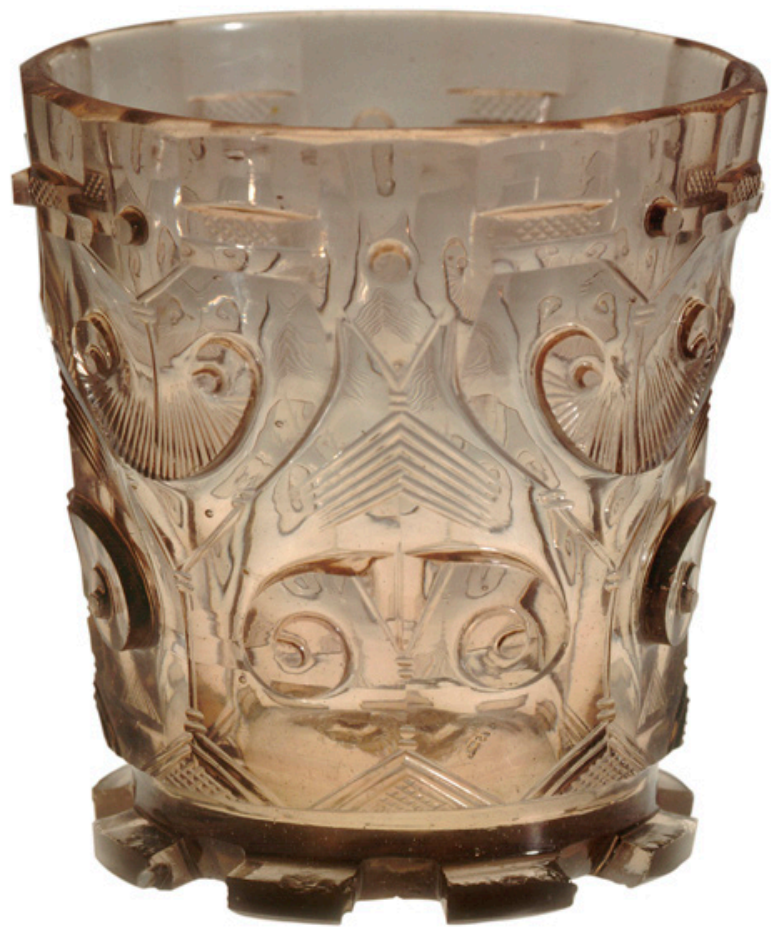

Fig. 11. St. Elizabeth glass or Hedwigsglas in possession of Martin Luther, 12th century[?], Art collection of the Veste Coburg, www.kunstsammlungen-coburg.de.

of historians in material culture the Elizabeth glass has now entered historical discourse. The glass has changed hands many times, and in the process it has been attributed with various healing and magical powers. It also served representative functions at court and, once stripped of its magical powers which soon were forgotten, it was used as a normal glass for drinking. Only in the course of becoming a collector's item and entering academic discourse was the lost memory of its former meanings reestablished and the material survival of the glass reinvested with magical power and historical significance as the 'St. Elizabeth glass'.

\section{Conclusion}

Lost in time and space: Migration, material culture, generation and memory have often been studied as isolated topics. However, a dynamic 
approach to the interplay of these phenomena opens up new ways of understanding the narrative, visual and material construction of glocal memoryscapes in the early modern period, as well as the spatial and generational dimensions of memory transmission. Whereas collective global memories have been analysed by historians of the twentieth century by focusing on 'memory activists', I have suggested a different analytical perspective by looking at how memory is constituted in social practices around shared practical understandings in specific situations and social sites. These social practices are construed as materially mediated activities, a perspective which acknowledges that objects also help to shape human sociability.

By using the experience of religious difference as a focal point of transnational memory formation in the early modern period, its materiality across time and space can serve as the material record of connections to other landscapes, natures and lived environments. The agents of memory transmission in the early modern period were people, written media and artefacts. Rejecting a merely cognitive understanding of memory, it has been argued that the meaning of memory was constituted in social practices at a specific time, situation and spatial location. 